\title{
Mixed Epithelioid and Spindle Cell Melanoma
}

National Cancer Institute

\section{Source}

National Cancer Institute. Mixed Epithelioid and Spindle Cell Melanoma. NCI Thesaurus. Code C66756.

A melanoma characterized by the presence of malignant large epithelioid melanocytes and malignant spindle-shaped melanocytes. 